УДК 364:347.61(477.86)

DOI: $10.15330 /$ esu. 1.139-146
Галина Михайлишин,

доктор філософських наук, професор,

ДВНЗ "Прикарпатський національний університет імені Василя Стефаника"

(м. Івано-Франківськ, Україна)

Galyna Mykhaylyshyn,

Doctor of philosophical science, Professor,

Vasyl Stefanyk Precarpathian national university

(Ivano-Frankivsk, Ukraine)

galmuh60@gmail.com

Мирослава Довzа, аспірант, ДВНЗ “Прикарпатський національний університет імені Василя Стефаника" (м. Івано-Франківськ, Україна)

Myroslava Dovga,

Post-graduate student, Vasyl Stefanyk Precarpathian national university (Ivano-Frankivsk, Ukraine)

mirosya29@meta.ua

\title{
СОЦАЛЬНЕ ПРОЕКТУВАННЯ ЯК ОДИН ІЗ ПРОГРЕСИВНИХ ЗАСОБІВ ПОДОЛАННЯ ПРОБЛЕМ МОЛОДИХ СІМЕЙ У ІВАНО-ФРАНКІВСЬКІЙ ОБЛАСТІ
}

\section{SOCIAL DESIGN AS ONE OF THE PROGRESSIVE MEANS FOR OVERCOMING PROBLEMS OF YOUNG FAMILIES IN IVANO-FRANKIVSK REGION}

В прочесі суспільних змін відбулося погіриения сочіокультурних умов життедіяльності різних категорій осіб (в наиому випадку молодих сімей), що спричинило низку невиріиених сочіальних проблем. Адже, однією із важливих проблем є низький рівень правових знань молодих людей, ио проявляються у неготовності до побудови та спільного сімейного життя. Тому робота з молодими сім'ями має бути спрямована на аналіз, прогноз та надания правовой допомоги иляхом навчания, інформувания та консультувания з питань прав, обов'язків та відповідальності членів молодих сімей у різних видах діяльності, зиайомство з пільгами, законодавчими і нормативними документами тоџо. Саме така діяльність сприятиме змічненню статусу молодої сім' 'ï, підвищить ї сочіальну значущість у суспільстві, що позитивно позначиться на підвищенні народжуваності та добробуту молодих сімей і зменшення кількості розлучених молодих сімей (413 молодих сімей із 590 сімей загалом за статистичними даними Головного територіального управління Юстичії в Івано-Франківській області управліния держсвної ресстрачії відділу РАЦСу у 2018 р.). Для вирімення низки проблем молодих сімей, які виникли в результаті цих змін нами розкрито суть та особливості соціального проектування, проаналізовано та показано важливість сочіального проекту для подолання проблем молодих сімей на основі чітко зазначених статистичних даних з відділу РАІСу Івано-Франківської області. Розглянуто різні конџептуальні положения поняття сочіального проектувания та сочіального проекту $i$ запропоновано ̈̈х авторські визначення. Також розроблено сочіальний проект для подолання проблем молодих сімей у Івано-Франківській області иляхом створення Мобільної групи з надання сочіально-правової та психологічної допомоги молодій сім' ̈̈.

Ключові слова: сочіальне проектування, сочіальний проект, Мобільна група з надання сочуільно-правової та психологічної допомоги молодій сім 'ї.

In the process of social change, the socio-cultural conditions of life of different categories of people (in our case, young families) deteriorated, which caused a number of unresolved social problems. After all, there are many problems, there is a low level of Orthodox knowledge of young 
people, who show their lack of ability to build and live together. Therefore, work with young families should be designed to analyze, predict and use legal assistance to educate, inform and advise on true, necessary and compulsory members of the young family collective in the various activities found with privileges, legislative and relevant legacy documents. This method should be increase the status of a young family, and maintains its well-considered importance in a society that is positively aware of its diminishing numbers of young people and the well-being of young people (413 young families out of 590 in total statistics from the Chief Local Justice Administration in the Ivano-Frankivsk region of management of the European RACS department in 2018). In order to solve a number of problems of young families that arose as a result of these changes, we have disclosed the essence and features of social design, analyzed and illustrated the importance of a social project to overcome the problems of young families on the basis of clearly specified statistics from the RACS Department of Ivano-Frankivsk District. Different conceptual provisions of the notion of social design and social project are considered and their author's definitions are proposed. Also, a social project to overcome the problems of young families in Ivano-Frankivsk district has been developed through the creation of a Mobile Group for the provision of social-legal and psychological assistance to the young family.

Key words: social design, social project, mobile group for provision of social-legal and psychological assistance to young families.

Постановка проблеми у загальному вигляді. На сьогоднішньому етапі розвитку суспільства українська держава перебуває в процесі різних складних перетворень зумовлених викликами сучасності. Тому сім'я (особливо молода сім'я) як соціальний інститут в результаті складних та швидких перетворень зазнала різких змін, що потягли за собою низку проблем. Однією із проблем є низький рівень правових знань людей, які $є$ дуже суттєвими і проявляються у неготовності до сімейного життя та низька соціальна захищеність з боку держави, результатом чого відбувається знецінення статусу сім'ї та іiі соціальної значущості у суспільстві, що негативно позначається на зниженні народжуваності дітей та добробуту сімей i збільшення кількості розлучень (по загальній статистиці по Україні 70\% розлучених сімей є саме молоді сім'ї, з них 50\% - молоді сім'ї з дітьми).

Таким чином, суспільні перетворення $\epsilon$ причиною появи різних проблем цільових груп клієнтів (в нашому випадку молодих сімей), які потребують негайного їх вирішення шляхом застосування нових соціальних інструментів. Новим таким прогресивним інструментом виступає соціальне проектування, що перебуває на етапі становлення та розвитку.

Аналіз останніх досліджень і публікацій. Питаннями соціального проектування, їі проблематикою, історичними аспектами, теоретичними та практичними основами займалися низка українських та вітчизняних науковців, зокрема Г. А. Антонюк (основоположник теорії соціального проектування та досліджував соціальне проектування в теорії державного управління ), Т. М. Дрізд (основоположник низки підходів до соціального проектування), О. В. Антонова, В. І. Безспалько, М. С. Коган, В. І. Курбатова, Д. В. Ланде, В. А. Лукова, Е. А. Самбурова (теоретичні основи соціального проектування), Бутченко Т.І. (практичні основи соціального проектування), О. І. Пометун (вивчав підготовку молоді до реалізації соціальних проектів) та багато інших дослідників, які вивчали різні питання соціального проектування.

Виокремлення невирішених раніше аспектів загальної проблеми. За даними відділу РАЦСу Івано-Франківської області, на Івано-Франківщині спостерігається зменшення кількості зареєстрованих шлюбів, що пов'язане із збільшення тенденції спільного прожиття разом без реєстрації сімейних стосунків. 
Якщо взяти Івано-Франківську область, то статистичними даними у 2018 році було укладено приблизно 7687 шлюбів з яких 3073 розпалося. Серед них: Богодчани (262 шлюби, з них 163 розлучення), Болехів (100 шлюбів, серед них 43 розлучення), Верховина (151 шлюбів, серед них 36 розлучень), Галич (253 шлюби, серед них 130 розлучень), Городенка (203 шлюби, серед них 109 розлучень), Долина (317 шлюби, серед них 160 розлучень), Івано-Франківськ (2784 шлюби, серед них 590 розлучень), Калуш м/в (499 шлюби, 214 розлучень), Калуш р/в (243 шлюби, 3 них 203 розлучення), Коломия м/в (581 шлюби, серед них 191 розлучення), Коломия р/в (243 шлюби, серед них 203 розлучення), Косів (342 шлюби, серед них 103 розлучення), Надвірна (503 шлюби, серед них 224 розлучень), Рогатин (167 шлюбів, серед них 84 розлучень), Рожнятів (355 шлюбів, серед них 208 розлучень), Снятин (300 шлюбів, серед них 154 розлучень), Тисмениця (184 шлюби, серед них 66 розлучень), Тлумач (184 шлюби, серед них 66 розлучень) і Яремче (140 шлюбів, 3 них 32 розлучення).

У Івано-Франківській області найбільше розлучень зареєстровано у молодих сім'ях, тривалість шлюбу яких складала до 5 років (2151 розлучень серед молодих сімей протягом 2018 року). Серед шлюбів зареєстрованих у актах цивільного стану $75,6 \%$ молодих пар не мали спільних неповнолітніх дітей, 17,5\% мали одну дитину, $6,1 \%$ - двоє дітей, а $0,8 \%$ сімейних пар, у яких офіційно шлюб зареєстровано при наявності 3-х і більше спільних неповнолітніх дітей, не було причиною припинити розлучення.

Постановка завдання. Метою статті є 3'ясувати суть та особливості соціального проектування, аналізувати та показати важливість соціального проекту для подолання проблем молодих сімей у Івано-Франківській області шляхом створення Мобільної групи 3 надання соціально-правової та психологічної допомоги молодій сім'ї.

Виклад основного матеріалу дослідження. Серед пріоритетних проблем побудови та розвитку майбутніх процесів в суспільстві значна роль відводиться проектуванню як формі випереджаючого відображення дійсності, створення прообразу передбачуваного об'єкта, явища чи процесу за допомогою специфічних методів. Проектування $\epsilon$ ще і певним циклом управління, що забезпечує реалізацію його інших функцій [8, с. 178].

Соціальне проектування - це конструювання індивідом, групою чи організацією дії, спрямованої на досягнення соціально значущої мети, яка $є$ локалізованою за місцем, часом і ресурсами. Сутність соціального проектування полягає в конструюванні бажаних станів майбутнього [3, с. 120].

На думку Курбатова В. І., соціальне проектування - це науково-теоретична $\mathrm{i}$ одночасно практична діяльність по створенню проектів розвитку соціальних систем, інститутів, об'єктів на основі соціального передбачення, прогнозування та планування їх соціальних якостей і властивостей. Це дає можливості керувати соціальними процесами і є вираженням того нового, що характеризує тенденції соціального розвитку. [7]. Тобто, соціальне проектування тісно переплітається з новими тенденціями соціального розвитку і тому має бути інновацією в соціальному розвитку суспільства.

Основоположником теорії соціального проектування $\epsilon$ Антонюк Г. А., який висвітлює його як розробку науково-обгрунтованої моделі раціональних характеристик конкретних соціальних організмів чи їх станів в контексті вирішення певних соціальних задач. В результаті чого соціальне проектування починає розумітися як універсальний та самостійний вид діяльності, що направлена на створення соціаль- 
них об'єктів, процесів, явищ, стає сполучної ланкою між виробником соціальних благ та споживачем [2, с. 12].

Вагомим внеском зробив Дрізде Т. М. як основоположник низки підходів до соціального проектування: об'єктно-орієнтований (соціальне проектування має на меті створення прообразу майбутнього об'єкту або модернізацію вже існуючого, $\mathrm{i}$ тут $є$ дуже важливим, що проектуватися можуть не тільки будівлі, підприємства, виробництва, як в попередні періоди, а й соціальні зв'язки, відносини, соціальна сфера в цілому), суб'єктно-орієнтований (соціальне проектування роздивляється як розробка проекту індивідом, який представляє інтереси певної групи людей, верств населення, соціальних прошарків) та проблемно-орієнтований (він виник пізніше, ніж попередні підходи, і у його центрі стоїть направлення на усунення соціальних проблем шляхом вироблення можливих варіантів їх вирішення $з$ урахуванням проведених досліджень та наявних ресурсів [2, с. 13]. Таким чином, у кожному підході є свої важливі елементи: у першому - це об'єкт проектування, у другому суб'єкт проектування, а в третьому виступає соціальне прогнозування.

На основі огляду літератури щодо соціального проектування, можна запропонувати таке визначення поняття Соціальне проектування - це самостійна теоретична та практична інноваційна діяльність індивіда, групи осіб чи організації, яка спрямована на конкретну цільову групу з наданням відповідно до іiі особливостей послуг за допомогою визначених ресурсів, конкретного часу, місця, методів та заходів спрямованих на досягнення очікуваних результатів (кількісні та якісні).

Таким чином, соціальне проектування та соціальний проект не одне i теж саме. Соціальне проектування $\epsilon$ інноваційною діяльністю в результаті якої саме створюється проект соціальної роботи. Тобто соціальний проект - це результат соціального проектування.

Проект соціальної роботи іноді розуміють як інтегровану систему, що складається із: сформульованих проектних цілей; створених для цих цілей соціальних установ, фізичних об'єктів, системи соціального захисту; розроблених та затверджених відповідних документів - програм, планів, кошторисів, розрахунків тощо; розрахованих матеріальних ресурсів - матеріальних, фінансових, трудових, часових; комплексу управлінських рішень, заходів 3 досягнення цілей [10].

На думку В.А. Лукова, коли говорят про проект, то мають на увазі мисленнєву конструкцію яких-небудь змін, котрі зарані сплановані та можуть бути реалізовані. Така конструкція може бути подана у вигляді, прообразу, i в ній є обов'язковий вольовий компонент - налаштованість здійснити задум [9].

В свою чергу, М.С. Коган визначає соціальний проект як опис конкретної ситуації, котра може бути поліпшена засобами реалізації певної системи методів та послідовних кроків їх використання [6].

Соціальний проект сприяє набуттю досвіду діяльності в тій чи іншій соціальній ролі, формує свідомість причетності до суспільства, інтенсивно розвиває особистісні функції: самосвідомість, самовизначення, самоствердження в існуючому соціумі. Соціальний проект сприяє формуванню ціннісно-смислової сфери, так як тут не моделюються соціальні умови, а реально існують, i проектна діяльність має соціальну, а отже, й особистісну значимість [5, с. 13].

Безумовно, що успішний соціальний проект $є$ результатом саме колективної діяльності спрямованої на покращення ситуації у соціальному середовищі, що здійснюється на визначеній проблемі конкретної цільової групи, території та часі і відповідно має послідовність у створенні та реалізації. 
Тому соціальному проекту притаманні такі особливості:

1. Проект завжди має мету (оскільки чітко визначені цілі є запорукою отримання конкретних результатів);

2. Проект завжди обмежений у часі та просторі (оскільки у проекту завжди $\epsilon$ початок і кінець);

3. Проект завжди реалізується в певному місці (соціальному інституті, громаді, регіоні тощо);

4. Кожен проект є по-своєму унікальний (оскільки виникає 3 нових ідей, які мають на меті специфічне вирішення проблеми на певному рівні) [4].

Розробка соціального проекту часто починається в умовах певної невизначеності, що вимагає дотримуватися деякої послідовності. Тобто, у процесі соціального проектування є своя логіка, етапи:

- аналіз суспільної проблеми ( пошук, вияв її суті);

- визначення мети;

- збирання інформації;

- на базі інформації визначається завдання проектування i те, яким параметрам воно має відповідати. Завдання - це частина концепції проекту;

- перевірка концепції;

- прийняття рішення (складання конкретної програми дій) [8, с. 179].

На основі аналізу думок вчених нами запропоновано власне визначення поняття соціальний проект, що є свого роду нововведення по вирішенню конкретних соціальних проблем з створення, покращення чи підтримки відповідних цінностей зазначеної цільової групи організаторами та виконавцями проектної діяльності, яке має здійснюватися послідовно.

Натомість, соціальне проектування, на нашу думку, - це самостійна теоретична та практична інноваційна діяльність індивіда, групи осіб чи організації, яка спрямована на конкретну цільову групу з наданням відповідно до іï особливостей послуг за допомогою визначених ресурсів, конкретного часу, місця, методів та заходів спрямованих на досягнення очікуваних результатів (кількісні та якісні).

У контексті підготовки молоді до реалізації соціальних проектів, О. І. Пометун, визначає їх як сукупність практичних дій, спрямованих на розв'язання конкретної соціальної проблеми місцевої громади, а участь молоді в таких проектах сприяє розвитку у неї емоційно-ціннісного ставлення до громадського життя, активності особистості, прагненню до громадянських дій та ефективного спілкування [11].

Соціальний проект має бути ідеальною моделлю, баченням майбутнього соціального існування. Предметом соціального проектування є сфера належного, що повинна грунтуватися на певному наборі цінностей, який піддається регулюванню на місцевому рівні, майже культивуватися. Забезпечення належного стану уможливлюється шляхом використання нормативного та ситуативних підходів. Причому критерії соціального проектування (соціальна-економічна ефективність, екологічна оптимальність, соціальна інтегрованість і керованість) мають бути визначені саме 3 реальної практики існування місцевих спільнот [1, с. 7].

Тому нами розроблений соціальний проект по наданню допомоги молодій сім'ї на рівні місцевих громад Івано-Франківської області. Найгірша картина 3 розлучень стосується громад: Косова (342 шлюбів (239 шлюбів серед молодих сімей), 3 них 60 розлучень (42 розлучення серед молодих сімей), Надвірна (503 шлюбів (352 шлюбів серед молоди сімей), з них 58 розлучень (41 розлучення серед 
молодих сімей), Калуша (618 шлюбів (433 шлюби серед молодих сімей, з них 108 розлучень (76 розлучень серед молодих сімей), Коломиї (824 шлюбів (577 шлюбів серед молодих сімей, з них 131 розлучення (92 розлучення серед молодих сімей) та Долини ( 317 шлюбів (223 шлюби серед молодих сімей, 3 них 55 розлучень (39 розлучень серед молодих сімей). Тому саме до цих громад, де найбільше проявляються проблеми молодих сімей та їх розпадів, нами розроблений соціальний проект по створенню Мобільної групи 3 надання соціально-правової та психологічної допомоги молодій сім'ї.

Даний соціальний проект називається “Освіта молодої сім'i”" та місцем реалізації передбачаєються такі ОТГ Івано-Франківської області, тобто в тих громадах, де зафіксовано найбільший показник по розлучених молодих сім'ях:

- Делятинська селищна громада (Надвірнянський район);

- Яблунівська селищна громада (Косівський район);

- Войнилівська селищна громада (Калуський район);

- Печеніжинська селищна громада (Коломийський район);

- Витвицька сільська громада ( Долинський район).

Соціальний проект передбачає співпрацю організаторів 3 викладачами та студентами, які допомагають вирішувати питання молодих сімей, також співпрацю 3 зазначеними громадами ОТГ, діяльність яких спрямована на роботу 3 молодими сім'ями.

Метою проекту $є$ підвищення рівня соціально-правової грамотності молодих сімей та соціально-правового захисту шляхом створення сучасної Мобільної групи 3 надання безкоштовної соціально-правової та психологічної допомоги молодій сім'ї на рівні ОТГ.

Завданнями проекту виступає:

1. Створити Мобільну групу 3 надання соціально-правової та психологічної допомоги молодій сім'ї

2. Проаналізувати ступінь поінформованості молодих сімей щодо подолання різних сімейних проблем.

3. Підвищити рівень правової обізнаності молодих сімей 3 їхніми правами, свободами та інтересами у сфері соціально-правового захисту.

Інноваційністю соціального проекту є:

1. Вперше цільовою групою виступає саме молода сім'я як мала соціальна група двох людей (чоловіка та дружини) з дітьми чи без них, які проживають разом не більше 5 років у громадянському шлюбі чи на основі взаємної довіри, що взяли на себе матеріальну та моральну відповідальність за всіх членів сім'ї, мають сприяти загальному добробуту та саморозвитку кожного із них, вести спільний побут, довіряти один одному і брати безпосередню участь у народженні та вихованні своїх дітей, а вік одруженої пари не може перевищувати 35 років

2. Вперше створено Мобільну групу з надання соціально-правової та психологічної допомоги молодій сім'ї задля підвищення їх правової обізнаності шодо захисту прав, свобод та інтересів на базі співпраці з адміністративними центрами.

3.Надання послуг саме молодим сім'ям, як особливій категорії осіб, що потребують навчання, надання правових послуг та консультування.

Соціальний проект розрахований на один рік і протягом цього часу нами заплановано виконання таких заходів:

1. Реклама соціального проекту про створення Мобільної групи 3 надання соціально-правової та психологічної допомоги молодій сім'ї. 
Підбір виконавців соціального проекту.

Налагодження співпраці з громадами ОТГ.

Створення інтернет-сторінки..

2. Опитування молодих сімей та проведення дослідження за допомогою соціальнопедагогічних методик (постійно)

3. Виїзд Мобільної групи в громади ОТГ та зустріч з молодими сім'ями.

4. Організація та проведення тренінгу .

5. Проведення розмов, години відкритих думок, спілкування та панорама правових питань $з$ молодими сім'ями

6. Бесіда з молодими сім'ями

7. Тематична зустріч 3 молодими сім'ями

8. Проведення семінарів з молодими сім'ями

9. Воркшопи з молодими сім'ями

10. Майстер-класи з молодими сім'ями

11.Індивідуальні консультації з молодими сім'ям відповідно до запитів (постійно)

12.Організація та проведення підсумкової конференції по соціальному проекту.

Тому від реалізації даного проекту ми очікуємо створити першу Мобільну групи з надання соціально-правової та психологічної допомоги молодій сім'ї, розвинути надання безкоштовної правової допомоги молодим сім'ям в результаті чого відбулося покращення життя молодих сімей, провести щонайменше 10 консультацій, покращити умови для розвитку соціально-правового захисту сім’ї, навчити та проконсультовати щонайменше 10 молодих сімей і підвищити рівень правової обізнаності серед молодих сімей на $10 \%$.

Також, сподіваємося що після закінчення даного проекту Мобільна група 3 надання соціально-правової та психологічної допомоги молодій сім’ї підготує до друку методичний посібник для роботи з молодими сім'ями та продовжить свою діяльність, поширить їі на території м. Івано-Франківська.

Висновки. Таким чином, реалізація соціального проекту про створення Мобільної групи з надання соціально-правової та психологічної допомоги молодій сім'ї (“Освіта молодої сім'ї”) має бути спрямована на аналіз, прогноз та надання правової допомоги шляхом навчання, інформування та консультування 3 питань прав, обов'язків та відповідальності членів сімей у різних видах діяльності, знайомство 3 пільгами, законодавчими і нормативними документами тощо. Саме така діяльність сприятиме зміцненню статусу сім'ї, підвищить ï соціальну значущість у суспільстві, що позитивно позначиться на підвищенні народжуваності дітей та добробуту сімей $\mathrm{i}$ зменшення кількості розлучених молодих сімей $\mathrm{y}$ громадах Івано-Франківської області.

\section{Література}

1. Антонова О. Соціальне проектування в теорії державного управління. Державне управління та місцеве самоврядування / А. Антонова. - Дніпропетровськ: ДРІДУ НАДУ, 2009. - С. 3-12.

2. 2.Дрідзе Т. М. Орлова Э. А. Основы социокультурного проектирования / Т. М. Дрізде, Э. А. Орлова. - Москва: Российский институт культурологии, 1995. - 148 с

3. Зарецький А. Д., Иванова Т. Е. Корпоративная социальная ответственность: мировая и отечественная практика: учебное пособие / А. Д. Зарецький, Т. Е. Иванова. - Краснодар: КСЭИ, 2012. $-231 \mathrm{c}$.

4. Звєрєва І. Д. Соціальна педагогіка: теорія і технології : підручник / І. Д. Звєрєва. - Київ : Центр навчальної літератури, 2006. - С. 147-160.

5. Киричук В. О. Технології проектування в практиці роботи загальноосвітнього навчального закладу: теоретико-практичний аспект: посібник / В. О. Киричук. - Київ: Інститут обдарованої дитини НАПН України, 2014. - 336 с. 
6. Коган М.С. Метод проектов и условия его эффективного применения в воспитательной работе / М. С. Коган. [Електронний ресурс].: - Режим доступу: http://www.websib.ru/vospitanie/04$05 /$ metod $1 / \mathrm{htm} /$.

7. Курбатов В.И., Курбатова О.В. Социальное проектирование: Учебное пособие / В. И. Курбатов, О. В. Курбатова. - Ростов н/Д.: Фенікс, 2001. - 416 с.

8. Ланде Д. В., Фурашев В. М., Юдкова К. В. Основи інформаційного та соціально-правового моделювання: навч. посіб. / Д. В. Ланде, В. М. Фурашев, К. В. Юдкова. - Київ: НТУУ "КПІ", 2014. $-220 \mathrm{c}$.

9. Луков В.А. Социальное проектирование: учеб. пособие. 3-е изд. / В. А. Луков. - Москва: Флинта, 2003. 240c.

10. Тюптя Л. Т. Іванова Л. Т. Соціальна робота (теорія і практика): навч. посібник для студентів вищих навчальних закладів / Л. Т. Тюптя, Л. Т. Іванова. - Київ: Центр навчальної літератури, 2004. $-408 \mathrm{c}$.

11. Пометун О.І. Молодь обирає дію: Соціальне проектування - новий підхід до виховання молоді. Метод проектів: традиції, перспективи, життєві результати: Практико зорієнтований збірник / О. І. Пометун - Київ: Департамент, 2003. - С. 327-333.

\section{References}

1. Antonova O. Social designing in the theory of public administration. Public Administration and Local Self-Government / A. Antonova. - Dnipropetrovsk: DRIDU NAPA, 2009. - p. 3-12.

2. 2.Dridze T.M. Orlova E. A. Fundamentals of Socio-Cultural Design / T. M. Drisde, E. A. Orlov. Moscow: Russian Institute of Culturology, 1995 - 148 p.

3. Zaretsky A. D., Ivanova T. E. Corporate Social Responsibility: World and Domestic Practice: A Study Manual / A. D. Zaretsky, T. E. Ivanova. - Krasnodar: KSEI, 2012. - 231 p.

4. Zvereva I. D. Social Pedagogy: Theory and Technology: Textbook/I. D. Zverev. - Kyiv: Center for Educational Literature, 2006. - P. 147-160.

5. Kirichuk V.O. Technology of design in the practice of work of a comprehensive educational institution: theoretical and practical aspect: manual / V.O. Kirichuk. - Kyiv: Gifted Child Institute of National Academy of Sciences of Ukraine, $2014-336 \mathrm{p}$.

6. Kogan MS The method of projects and the conditions for its effective use in educational work / MS Kogan. [Electronic resource] .:- Access mode: http://www.websib.ru/vospitanie/04-05/metod $1 / \mathrm{htm}$ /.

7. Kurbatov VI, Kurbatova O.V. Social design: Tutorial / VI Kurbatov, O. Kurbatov. - Rostov n / A: Phoenix, 2001. - 416 pp.

8. Lande D. V., Furshev VM, Yudkova KV Fundamentals of informational and socio-legal modeling: teaching. manual / D. V. Lande, V. M. Furshev, K. V. Yudkova. - Kyiv: NTUU "KPI", $2014-220$ p.

9. Lukov VA Social design: study. allowance 3rd ed. / V. A. Lukov. - Moscow: Flint, 2003. 240p.

10. Tyupta L.T. Ivanova L.T. Social work (theory and practice): Teach. a manual for students of higher educational institutions / L. T. Tyuptya, L. T. Ivanova. - Kyiv: Center for Educational Literature, 2004. $-408 \mathrm{p}$.

11. Pometyn O.I. Youth chooses action: Social design - a new approach to youth education. Method of projects: traditions, perspectives, life results: Practically oriented collection / O. I. Pometun - Kyiv: Department, 2003. - P. 327-333.

Одержано статтю: 19.09.2019

Прийнято до друку: 16.10.2019 